\title{
Evolution of the sandy coast of Gabes, S-E of Tunisia
}

\author{
Ikram Bardi ${ }^{1}$, Mongi Souayed ${ }^{1}$, Saadi Abdeljaouad ${ }^{1}$ \\ Laboratory of Mineral Resources and Environment, department of Geology, \\ Faculty of Sciences of Tunis, University of Tunis-El-Manar, University Campus, 2092, Tunisia.
}

\begin{abstract}
The Southern part of the Gulf of Gabes, SE of Tunisia, is a microtidal sandy coast. It is recently developing a series of sand spits. We seek to determine the evolution of the coast over the past decades and to establish the hydrodynamic conditions that led to this development. To do this, we relied on the diachronic study of the shoreline from aerial photographs from 1985 and 1997. Thus, the evolution of the coast is subject to continuous changes that reflect an active sediment dynamics.
\end{abstract}

Keywords- Littoral drift, morphological evolution, sandy coast, sediment dynamics, spits.

\section{Introduction}

The Gulf of Gabes occupies the greater part of the East coast of Tunisia. It is characterized by an extensive continental shelf, and low slope spanning about $380 \mathrm{kms}$ from the coast. This is an original microtidal environment, where the tidal range is exceptional during periods of bright-waters tide which reached 2,3 $\mathrm{m}$ [1]. The southern coast of the Gulf of Gabes, which stretches about $20 \mathrm{kms}$ from the port of Gabes and wadi Ferd (Fig. 1) is a sandy coast [2]. The average particle size in the fore shore is about $0,11 \mathrm{~mm}$, at the spits is $0,15 \mathrm{~mm}$, and in the mouth of wadis is about $0,21 \mathrm{~mm}$. Also, note that three large wadis (Gabes, Sourrag, Ferd) that feed this coast occasionally during floods. In addition, the coast has a low slope with an average of about $0,5 \%$, according the bathymetry we realized in 2006 [2]. This coast is marked by recently individualized spits. Tow spits sides of the estuary of the wadi Ferd dotted with lagoons crossed by tidal channels; and spit that extends south of the wadi Sourrag (Fig. 1).

The objective of this study was to determine the morphological evolution of this part of the coast in recent decades.

The analatycal work based on the spatio-temporal evolution of the coastline, from aerial photographs from 1985 and 1997, covering the study area in southern Tunisia Lambert projection. Mapping the coastline was conducted within the Tunisian office of Topography and cartography (OTC) by the photogrammetric processing.

\section{Result And Discussion}

The coast of Gabes shows a remarkable evolution over the period from 1985 to 1997, marked mainly by recent emergence of spits that didn't exist before 1985 [3]. We observed two spits on both sides of the estuary of wadi Ferd (Fig. 1), the north spit is $2000 \mathrm{~m}$ long and the southern side is about $1500 \mathrm{~m}$, making their shelters two lagoons crossed by tidal channels (based on field observation). Note also a spit south of the wadi Sourrag extends about more than $2 \mathrm{~km}$. This morphology exists up today.
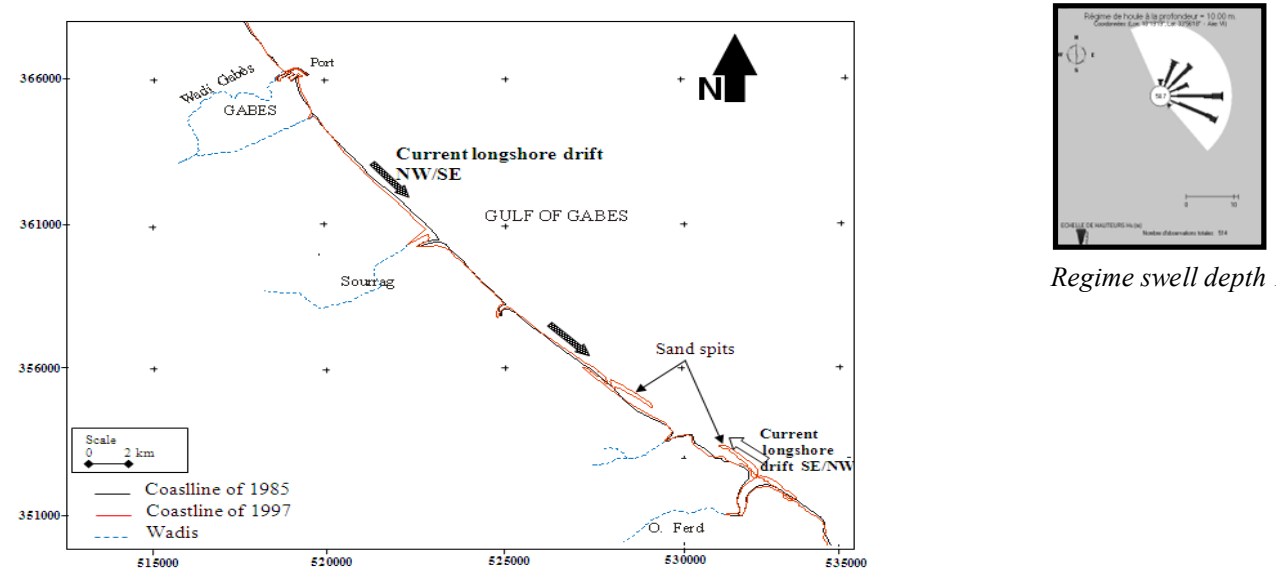

Regime swell depth 10 m

Fig. 1: Evolution of the coastline from 1985 to 1997 (based on aerial photography) 
The evolution of the coast shows that the south coast of the city of Gabes, is subject to an active sediment dynamics. This coastal strip is supplied with sand original river, by wadi Gabes, Sourrag and Ferd during heavy floods. In deed flows are violent and torrential during heavy rainfall causing floods, such as the 1990, 1995, 2003 and 2005 when rainfall was respectively $380 \mathrm{~mm}, 550 \mathrm{~mm}, 220 \mathrm{~mm}$ and $270 \mathrm{~mm}$ [4]. The quantities of sediment drained were important and therefore cause significant stream sediment input to the coast. These sediment are involved in fattening coast, because in the mouth area they enter on hydrodynamic interaction with the tidal currents, active in the channel mouth during periods of bright-water, and longshore currents. These are highlighted by the Coastal Modeling Systeme (C.M.S) [2], and are responsible for the formation and evolution of these spits. The drift depend of the direction of swells; indeed, the swells that spread directions $\mathrm{N}$ to $\mathrm{NNE}$ with significant wave height $\mathrm{Hs}=1,5 \mathrm{~m}$ and peak period $\mathrm{Tp}=7 \mathrm{~s}$, produce a longshore current direction NW-SE. While, swells directions $\mathrm{E}$ (with $\mathrm{Hs}=1,5 \mathrm{~m}, \mathrm{Tp}=7 \mathrm{~s}$ ) and $\mathrm{SE}$ (with $\mathrm{HS}=0,5 \mathrm{~m}, \mathrm{Tp}=5 \mathrm{~s}$ ) produce a longshore direction SE-NW. Both drifts supply the coast continuously by fine sediments and thus contribute to sediment transport along the coast, allowing the development of spits.

\section{Conclusion}

The morphological evolution of the sandy coast is mainly marked by appearance of spits. This is controlled in part by the continental sediment supply from wadis, flowing into the coast during floods. On the other hand by longshore currents that are responsible for the transit along the coast, namely drift SE-NW direction and the NW-SE direction, which depend of direction of swells.

\section{Acknowledgements}

The authors wish to thank Ms. Radhia Souissi from laboratory of mineral resources and environment of faculty of Tunisia; and the coastal oceanographic engineering group (GIOC) from the university of Cantabria in Spain.

\section{References}

[1] O.T.C (Office of Topography and Cartography), "Tide calendar of Gabes, Tunisia," Report, 2005, 30 p.

[2] Bardi I., Morphodynamique de la côte sableuse microtidale à barres le long de la frange littorale Gabès-Oued Ferd, (Golfe de Gabès-Tunisie) Ph.D Thesis, Faculty of sciences of Tunis, University of Tunis El Manar Tunisia, 2010.

[3] BARDi I., ABDELJAOUAD S. et SOUAYED M. (2011). Evolution du trait de côte de Gabès-oued Ferd (SE de la Tunisie). Proc, $2^{\text {nd }}$ Conf. Internat. Méditerranean Coastal and Maritime, Tanger, Maroc, 2011, 129-132.

[4] D.R.E, (Directorate of water resources), "Report Gabès, Tunisia", 2005, 40 p. 